\title{
Migration intentions of graduate students of medical universities in Russia and some CIS countries
}

\author{
Valeriia G. Oksinenko ${ }^{1}$ \\ 1 Lomonosov Moscow State University, Moscow, 119994, Russia
}

Received 17 October 2019 • Accepted 2 December 2019 • Published 30 December 2019

Citation: Oksinenko V (2019) Migration intentions of graduate students of medical universities in Russia and some CIS countries. Population and Economics 3(4): 65-85. https://doi.org/10.3897/popecon.3.e49754

\begin{abstract}
The shortage of young medical workers in Russia is a long-standing and acute problem; its solution, even in part, is impossible without taking into account a whole set of factors. An empirical analysis of the results of the survey of graduates of medical and non-medical specializations in Russia and CIS countries gives grounds to identify graduates of medical faculties as a homogeneous group, which has similar migration patterns and relatively low variance in the impact of various factors on these patterns. When making decision about migration for employment graduates of medical specialties are less susceptible to the imbalance in the development of regions of Russia, but more sensitive to social factors. The findings of the paper confirm the importance of ongoing efforts in the field of social and economic policy keeping in mind its potential effectiveness to retain medical workers in regions of Russia.
\end{abstract}

\section{Key words}

migration of medical workers; migration of graduates; migration of university graduates; migration policy.

JEL Codes: I18, J62, J68

\section{Introduction}

Migration of university graduates is a relevant issue for the majority of countries, including the Russian Federation. Obtaining higher education is one of the most important factors of human capital of the country as a whole and its regions. However, since the times of the USSR in Russia there is a noticeable differentiation of universities by status: the most 
prestigious universities are located in the largest cities while in most cities which are not big regional centers there are no higher educational institutions. This situation causes outflow of talented young people to major cities and they often do not return to their home areas: according to educational migration statistics, for many years the outflow exceeded the inflow in most regions (Ledenyova 1995; Chudinovskikh et al. 2003). This situation is a challenge for small and medium-sized settlements: it results in population ageing and a decline in the quality of human capital.

An important point within this issue is the migration of young medical workers. According to experts, for a long time Russia is facing a shortage of medical workers of various profiles, both with secondary and higher professional education. According to the Minister of Health of the Russian Federation Veronika Skvortsova, "the shortage of doctors of primary care is 10,700 district therapists and pediatricians and about 24,000 specialists in 94 medical profiles." Meanwhile, according to forecasts "two to three years will be sufficient to completely offset this deficit" (Minzdrav nadeetsya... 2019). Systemic measures that have already been adopted and primarily concern young professionals will are to have positive results in the field.

In 2012 the "Zemsky Doctor" program was launched; the purpose of the program is to attract doctors to work in the settlements with population less than 50,000. In the first year of the program, medical institutions of villages and small towns in the country were replenished by 8,000 medical workers, by the beginning of 2019 this number reached 29,000 (Chem obernetsya... 2019). Implementation of the program is planned to be continued, at the moment the directions of its improvement are being discussed (in particular, increasing the maximum age of participants, which is currently 50 years). At the same time, despite quite obvious positive outcomes, implementation of the program resulted in a loss for rural hospitals: using the benefits of the program, rural doctors tended to move to small towns for work (Chislennost' vrachei... 2019). The program also turns to be not effective in certain regions, in particular, northern ones (Kak v regionakh sochinyayut... 2018). Therefore, the issue of financial and social support of doctors working in hospitals of small towns and villages remains open and continues to be acute, including in academic literature (Kalashnikov and Likhacheva 2017).

Medical workers are often dissatisfied with working conditions, namely, the level of wages, the quality of medical equipment and hospital facilities. According to the President of the National Medical Chamber Leonid Roshal, "The lack of personnel cannot be solved without introduction of assignation of graduates who have been trained at the expense of the state. But the graduates are to be assigned not to drudgery but to normal conditions" (Roshal 2019). Thus, attention is focused on the need of state assistance to the regions in terms of improving conditions for attracting medical workers.

International migration is another resource to solve the problem of shortage of medical workers in Russia. In the list of professions that give the right to a simplified procedure for acquisition of Russian citizenship (Federal Law of 01.05.2016 N 124-FL), 21 out of 74 positions are medical and pharmaceutical workers of different profile and level of qualification. However, due to the uncompetitive by world standards level of wages in the industry, it is hardly possible to expect numerous inflow of physicians from other countries (Denisenko and Chudinovskikh 2015). Currently there is an imbalance in the supply of medical workers in different regions of the country. According to statistics of the Ministry of Health of the Russian Federation, in 2017 the average supply of the country with medical personnel amounted to 37.4 medical workers per 10,000 population, though this indicator varies from 
region to region. Thus, the lowest indicator in the Kurgan oblast is 24.7 , and the highest is in St. Petersburg - 57.7.

Table 1. Number of doctors by federal districts of the Russian Federation in 2016-17.

\begin{tabular}{lllll}
\hline \multirow{2}{*}{$\begin{array}{l}\text { Administrative regions of the } \\
\text { Russian Federation }\end{array}$} & \multicolumn{2}{l}{$\begin{array}{l}\text { Doctors } \\
\text { number of doctors }\end{array}$} & $\begin{array}{l}\text { doctor ratio (per 10,000 } \\
\text { population) }\end{array}$ \\
\cline { 2 - 5 } & $\mathbf{2 0 1 6}$ & $\mathbf{2 0 1 7}$ & $\mathbf{2 0 1 6}$ & $\mathbf{2 0 1 7}$ \\
\hline Russian Federation & $\mathbf{5 4 4 , 4 5 8}$ & $\mathbf{5 4 8 , 4 1 4}$ & $\mathbf{3 7 . 1}$ & $\mathbf{3 7 . 4}$ \\
Central Federal District & 144,998 & 146,289 & 37.0 & 37.3 \\
City of Moscow & 51,796 & 52,598 & 41.8 & 42.5 \\
Northwestern Federal District & 58,876 & 59,671 & 42.4 & 42.9 \\
City of St. Petersburg & 29,770 & 30,481 & 56.4 & 57.7 \\
Southern Federal District & 56,459 & 56,875 & 34.4 & 34.6 \\
North Caucasus Federal District & 33,516 & 34,027 & 34.3 & 34.8 \\
Volga Federal District & 106,729 & 107,419 & 36.0 & 36.2 \\
Ural Federal District & 42,751 & 42,657 & 34.6 & 34.6 \\
Siberian Federal District & 72,830 & 73,092 & 37.7 & 37.8 \\
Far Eastern Federal District & 24,864 & 25,120 & 40.2 & 40.6 \\
\hline
\end{tabular}

Source: (Statistical Digest 2017).

Within regions there is a problem of outflow of doctors from rural to urban areas. According to the statistics of the Ministry of Health, the doctor ratio in rural areas throughout the country in 2017 amounted to 14.8 doctors per 10,000 persons, while in a number of regions of the Central and North- Western Federal Districts this figure did not exceed 10, and in the Pskov oblast it is only 1.3 ((Statistical Digest 2017). In turn, large cities are more attractive for medical workers than small ones. The most acute problem is the shortage of young doctors; in some regions hospitals employ retired doctors, who may reach 70 to 80 years of age (Kak v regionakh boryutsya 2019).

The purpose of this study is to identify the factors that determine decision on migration by graduates of medical universities and faculties, in order to formulate and implement measures that would encourage students to return homeward after graduation. It is to be noted that the study does not distinguish between internal and international migration; it emphasizes the reluctance of graduates to return homeward as a whole. For this purpose, the following tasks are solved:

1. Identification of the factors that determine formation of migration intentions of graduates of medical and non-medical specialties on the basis of analysis of global and Russian academic literature;

2. Identification of factors that determine migration patterns of university graduates in the Russian Federation and some CIS countries (Moldova, Kyrgyzstan and Tajikistan);

3. Identification of differences in migration intentions of graduates of higher education institutions in medical specialties from students of other specialties and the reasons for these differences. 
The empirical basis for the analysis is primary data collected within a survey "Assessment of migration potential of graduate students of higher educational institutions of CIS countries" supported by the Fundamental Research Program of the Higher School of Economics (hereinafter - the Survey).

\section{Review of literature on migration of university graduates}

Migration of young professionals, especially university graduates, is a particular issue of migration policy in many countries. Research of many foreign authors is dealing with this topic.

From the perspective of migration policy, the study of factors of return migration of university graduates is significant. Earlier it was considered only in the framework of discrepancies between supply and demand in the local labour market (Fielding 1992; Halfacree 2004; Haartsen and Thissen 2014). In later works a number of other factors are considered. For example, Dustmann and Glitz (2011) emphasize the deep relationship between education and migration in society. Rérat (2014b) focuses on social factors: according to his study, graduates who have or are about to start a family or who intend to continue living with their parents are likely to return home after graduation, although the availability of job opportunities in their home region is also significant. Heckert (2015) finds a direct correlation between the intensity of educational migration and the solvency of households. Faggian and McCann (2009) prove the importance of economic and innovative development of home regions for return graduate migration. In most recent works, attempts are made to draw attention to the psychological characteristics of the graduates themselves as factors potentially influencing their attitude to return migration. For example, $\mathrm{Wu}$ and Wilkes (2017), in addition to the classical push and pull factors, analyze the attitude of graduates to understanding of "home" and, on this basis, predict the likelihood of return for different groups of migrants.

There is a significant number of research focused on the issues of international migration of university post-graduates. Jenny's paper (2013) found that the most important factors for deciding on international migration after graduation are: assistance of interested schools (information about study abroad and provision of grants), participation of students in specialized training courses, and the availability of a short-term work visa. Kerr and co-authors (2016) argue that the main reason for non-return of graduates who have studied abroad to their homeland is high costs related to the level of economic well-being of their country and difficulty of finding a job in it. An important contribution to the study of the issue is made by review works (Dustmann and Glitz 2011; Fargues 2019) which clearly reveal a deep relationship between migration and education but indicate its different manifestation in different countries, as well as the need to improve data collection and processing in order to study the issue in greater detail.

In Russia, the issues of migration of university graduates and its effects are analyzed in: Varshavskaya and Chudinovskikh (2014), Chudinovskikh et al. (2003), Kashnitsky (2015), Ledenyova (1995) and others. Some authors highlight the "brain drain" issue (Ledenyova 1995); earlier it was widely discussed in the media and in political discussions. The book by Denisenko, Donets and Chudinovskikh [Chudinovskikh et al. 2003) presents the results of a wide-scale survey of migration intentions of students of higher educational institutions of Russia from the perspective of their returning to native regions; according to the survey the key factor of decision on returning is the social and economic status of the student' family. 
The article by Varshavskaya and Chudinovskikh (2014) based on the statistical analysis of some of the data obtained in the framework of the Survey, a conclusion is drawn about the intention of graduates of Russian universities to internal migration due to "economic impracticability" of return to their homeland.

A special group among graduates of universities is represented by graduates of medical faculties and specializations. This is due not only to the special status of such graduates as members of society, but also to the constant shortage of qualified medical professionals in many countries.

The world academic literature pays special attention to international migration of health professionals. For example, Boncea (2015) shows that medical workers who have left their country are ready to return in the future, only if appropriate incentives are created. Perry and Clark (2012) prove a direct correlation between the level of punishment among health workers for their negligence and their migration intensity. Special attention is paid to the migration of junior doctors. Ramos and Alves (2017) point at the need to develop a special strategy to retain medical workers.

In different countries the system of attracting and retaining medical personnel is at different stages of development. It is often based on national peculiarities and cannot be easily transmitted to other countries. A rather successful practice for attracting and retaining doctors in the UK is based on financial support: research grants are provided to young health professionals; special scholarships are paid to those who come for study from rural areas and are willing to return to their home country after graduation; medical specialists recruited from abroad are granted numerous benefits, in particular, the cost of accommodation in a new place of residence (Aronson 2011; Verma et al. 2016). In South Africa, special emphasis is placed on the altruism of young doctors: they are willing to go to work in the countryside because they are aware of this as part of their mission (Rose and Janse van Rensburg-Bonthuyzen 2015). A sense of belonging to the community is very important for young people, so young doctors are often sent to new places of work in teams that enables creating communities at places of their work.

In Russian academic literature this topic is currently not sufficiently researched, primarily because of the lack of reliable data. Nevertheless, in existing works the emphasis on the need to improve measures of management of internal and international migration of medical workers is very clearly traced. Denisenko and Chudinovskikh (2015), Tarasenko and Khoreva (2016), considering the experience of other countries in attracting qualified medical personnel from abroad, make their recommendations to public authorities in the field.

Summarizing, it is important to note that migration decisions by graduates are influenced by a variety of social, economic and political factors; they are to be carefully studied on the basis of reliable empirical data that allows to test the hypotheses.

\section{Migration intentions of graduate students according to the Survey data}

To study migration intentions of students of medical specialties specific to Russia, statistical and regression analysis of the Survey data was carried out; the results are presented hereafter. Due to the wide coverage, the data allow to compare migration and labour strategies of students, which differ by place of study, financial situation, specialization and other variables. In addition to the data on Russian medical students, the Survey adopted the results 
of similar surveys conducted among graduate students of medical universities in Chisinau (Moldova), Dushanbe (Tajikistan) and Bishkek (Kyrgyzstan).

In the course of the Survey in Russia, 6,720 students from 29 universities were interviewed, including 1,954 respondents from 9 educational institutions of medical profile. 164 students (about $2.5 \%$ of the number of respondents) were foreign students in Russia.

In the territory of other CIS countries, a total of 1,021 students were interviewed, including 150 students at Tajik State Medical University, 433 students at Kyrgyz-Russian Slavic University and 438 students at Moldovan State University of Medicine and Pharmacy.

\section{Box 1. Russian students sample description}

\section{The Survey scope}

Students of the universities of all federal districts of the Russian Federation except North Caucasus, totally from 13 cities took part in the Survey. The sample covered universities of different sizes: from multidisciplinary federal (Lomonosov Moscow State University) to highly specialized regional (Ufa State University of Economics and Service). The full list of universities covered by the Survey is given in Annex 1.

Students' study forms

In Russia, 1,477 students studied at the bachelor's degree program, 3,871 at the general 5-year program, 563 at the master's degree program and 809 other respondents did not specify their program of study. The fact that most of the students studied in the general 5-year program is due to the fact that the main data set was collected in 2013, when most universities had not yet switched to a two-tier system of higher education.

Over three-quarters of the students surveyed do not pay tuition fees. At the same time, for students of non-medical specialties, the share of students on a commercial basis is $21 \%$, for students of medical specialties this indicator is even lower $-15.4 \%$ (Annex 2). To a high degree, this is due to the relatively small number of "commercial places" at medical faculties of higher education institutions.

Sex and age composition of respondents

Among the respondents, $67.3 \%$ are girls and $32.7 \%$ are men. This imbalance is due to the fact that the survey was conducted at faculties with predominantly female composition: humanitarian, pedagogical and medical. The average age of respondents is 22 years. Only $5 \%$ of respondents have children, $15 \%$ are or have been married.

\section{Local residents / residents of other cities}

On average, the number of non-resident students and those studying at the university of their hometown is roughly equal, although there are significant differences between universities, often not correlated with their status or city (Annex 3).

As for medical universities, there is a higher share of non-resident students: they account for almost $60 \%$ of the respondents. This fact can be explained by the specificity of medical education: not all universities include medical faculties, therefore school graduates who wish to study medicine are forced to go to other cities for study.

The Survey data were processed by means of descriptive analysis (including construction of cross tables with the most relevant indices) and regression analysis in which two key hypotheses were tested. The first one was applied to the totality of students interviewed and was connected with the factor of socio-economic development in the native settlement of the graduate: the worse the graduate's wage prospects, the lower the probability of return. 
The second hypothesis was related exclusively to medical students: for them the impact of all factors, especially those that contribute positively to the decision to return homeward, is stronger than for the totality of students.

Migration intentions in different groups of graduates differ significantly. The results of respondents 'responses to the question on their migration patterns are presented in Table 2.

Table 2. Migration intentions of students (as a percentage of the total number of respondents in the group).

\begin{tabular}{|c|c|c|c|c|c|c|c|}
\hline & \multicolumn{2}{|c|}{ All students } & \multicolumn{2}{|c|}{ Local residents } & \multicolumn{3}{|c|}{ Residents of other cities } \\
\hline & $\begin{array}{c}\text { To go } \\
\text { abroad }\end{array}$ & $\begin{array}{l}\text { To go to } \\
\text { another } \\
\text { location } \\
\text { within the } \\
\text { country }\end{array}$ & $\begin{array}{c}\text { To go } \\
\text { abroad }\end{array}$ & $\begin{array}{l}\text { To go to } \\
\text { another } \\
\text { location } \\
\text { within the } \\
\text { country }\end{array}$ & $\begin{array}{l}\text { To go } \\
\text { abroad }\end{array}$ & $\begin{array}{l}\text { To go to } \\
\text { another } \\
\text { location } \\
\text { within the } \\
\text { country }\end{array}$ & $\begin{array}{c}\text { To return } \\
\text { homeward }\end{array}$ \\
\hline $\begin{array}{l}\text { Russia } \\
\text { (all specialties } \\
\text { excluding } \\
\text { medical) }\end{array}$ & 8.25 & 66.6 & 10 & 9 & 6.3 & 62.3 & 9.1 \\
\hline $\begin{array}{l}\text { Russia (medical } \\
\text { specialties) }\end{array}$ & 4.7 & 58.2 & 7 & 70.1 & 3.1 & 50 & 22.6 \\
\hline $\begin{array}{l}\text { Chisinau } \\
\text { (medical } \\
\text { specialties) }\end{array}$ & 28.3 & 3.0 & 10.4 & 0 & 7.8 & 4.1 & 12.2 \\
\hline $\begin{array}{l}\text { Dushanbe } \\
\text { (medical } \\
\text { specialties) }\end{array}$ & 11.56 & 3.4 & 13.6 & 5.1 & 10.2 & 2.23 & 32.95 \\
\hline $\begin{array}{l}\text { Bishkek (medical } \\
\text { specialties) }\end{array}$ & 20.8 & 2.6 & 18.9 & 2.6 & 27.8 & 2.8 & 8.3 \\
\hline
\end{tabular}

Source: The Survey data

As can be seen from the table, for Russian students there is quite a clear desire to leave to another location within the country after graduation, while for students from CIS countries the intention to leave the country is more frequent. It is also important to note that a significantly higher percentage of non-resident medical students plans to return homeward after graduation (22.6\% versus $9.1 \%$ for students of other specialties). It is interesting to note the divergent preferences of Russian graduate students regarding migration within the country: among medical students who study in their hometown, the percentage of those who tend to migrate to another part of Russia is higher than among non-resident students; the reverse is true for non-medical students.

\section{Factors influencing migration intentions}

In order to explain the differences, a more detailed analysis of the factors influencing students' decisions related to migration is necessary. 
One of the main reasons for a university graduate's return homeward is admission to the university as an employer-backed enrolled student. Among respondents from Russian non-medical universities only 162 students (around 3\% of the number of respondents in the group) are employer-backed enrolled students. The share of local and non-resident students among them is roughly equal. Among medical students, the share of employer-backed enrolled students is much higher - 22\% (419 respondents); non-resident students predominate among them (Annex 4). As to medical universities of CIS countries the situation is again radically different: in Dushanbe there are only 2 employer-backed enrolled students, in Kishinev - 0, and only in Bishkek, 6.55\% of medical students are enrolled with an employer-backed contract.

High percentage of employer-backed enrolled students in medical specialties can be possibly explained by more conscious approach in choosing this direction of studies and, accordingly, future profession. This is confirmed by the students' responses. Among students of specialties other than medical only $46 \%$ of respondents declared a desire to work in their received specialty while among medical students this share was $82 \%$. Among medical students in CIS countries this share is also high: in Bishkek - 56\%, in Dushanbe - 76.5\%, in Chisinau - 93.2\% (Figure 1).

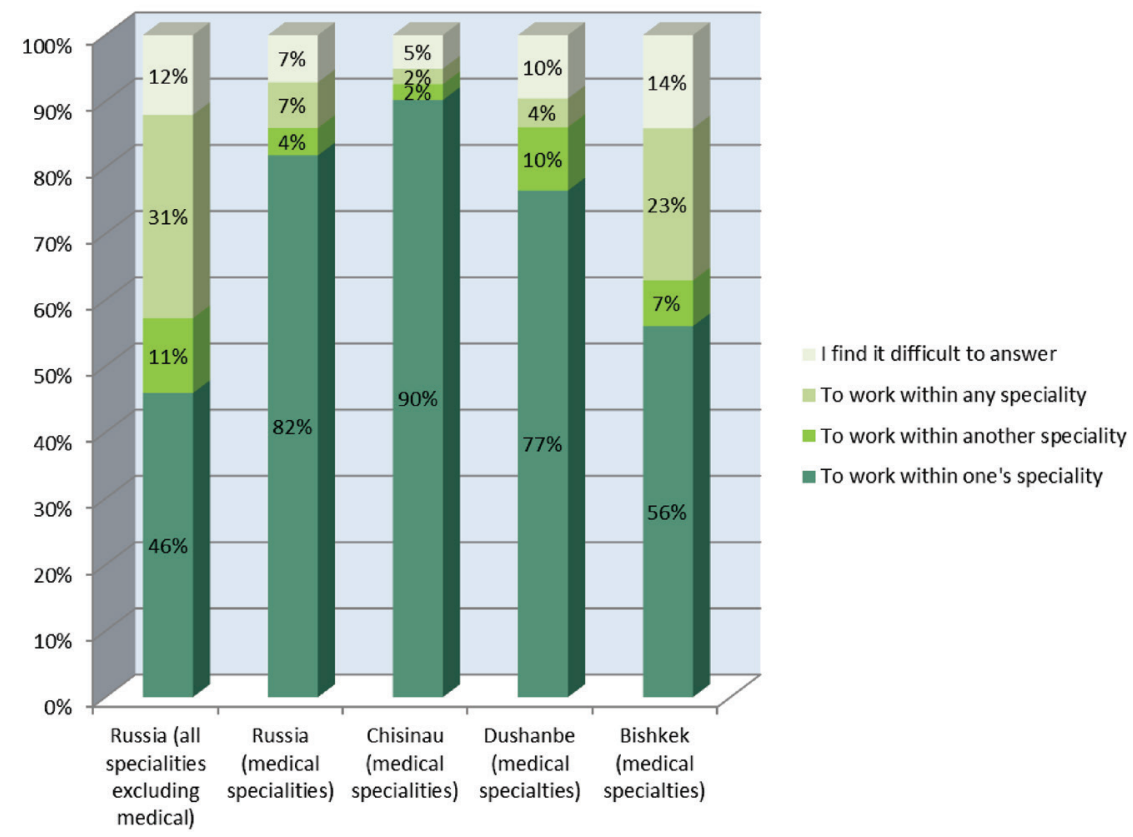

Figure 1. Further employment intentions of graduate students. Source: The Survey data

It is also important to note the relatively large number of respondents among non-medical students who declared that they are ready to work in any profession after graduation. As to medical students, they are definitely oriented to work in medicine. In addition to a conscious approach to the choice of profession, future doctors are in demand in all settlements regardless of their size. As for students of other specialties, their belief in the demand for the chosen profession is clearly lower. 
Already during the period of the student's study the specificity of employment works as a factor of future job choice. Within the Survey, students were asked whether they had job. Among non-medical students, 39\% answered that they currently have a permanent or temporary job, with less than half of the respondents working in the specialization of their training. Among medical students, $46 \%$ of respondents answered that they combine work and studies, while over half of this number, $60 \%$, are employed in their specialty. Among medical students in CIS countries, the proportion of those currently working varies, but on average the majority also works in their specialty (Figure 2).

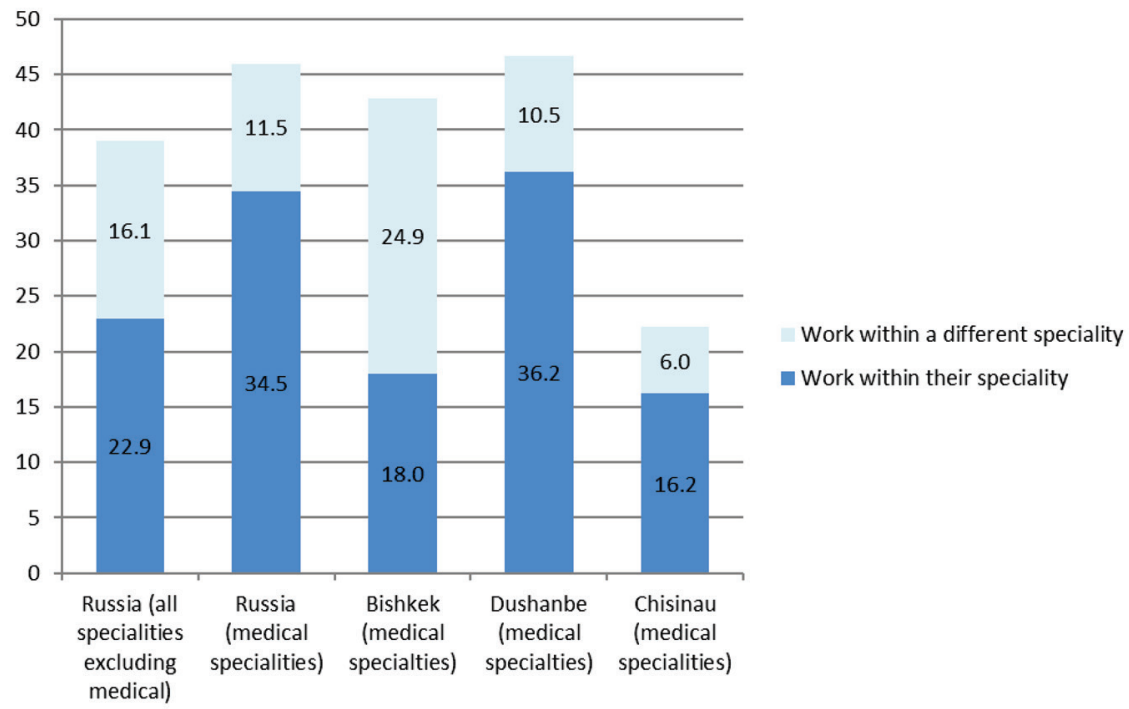

Figure 2. Availability of work for students at the time of study. Source: The Survey data

Medical students are generally more satisfied with their specialty and, importantly, have more stable professional intentions than students of other specialties. Although the differences are not so large for each individual criterion, their joint consideration proves the above-stated thesis. In particular, in response to the question: "If you had the opportunity to re-select your education profile, what would you choose?" - $52.7 \%$ of medical students from Russian universities answered that they would change nothing (against $47 \%$ of respondents studying in non-medical specialties). Among medical students in other CIS countries an even higher percentage of respondents would not change the profile of education: in Bishkek - 58.7\%, in Dushanbe - 79.7\%, in Chisinau - $73.7 \%$.

Figure 3 shows what students would prefer to change: nothing, the university (within the same specialty) or the specialty itself. $12.7 \%$ of medical students in Russia, despite the desire to choose another university, would still prefer to retain their specialty or faculty; in the general sample of respondents in Russia there were less adherents of their specialty $-9.4 \%$.

Summing up the statistical analysis, we conclude that medical students in Russia and in CIS countries are characterized by a more conscious approach to the choice of future profession and a tendency not to change their decision neither during the course nor at graduation. However, differences in migration patterns of medical students and students of other specialties are negligible, so we proceed to the last stage of work - regression analysis. 


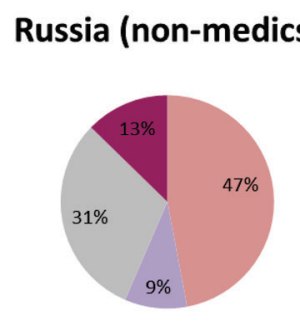

\section{Dushanbe}

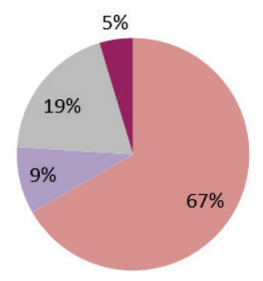

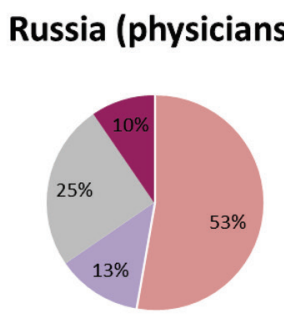

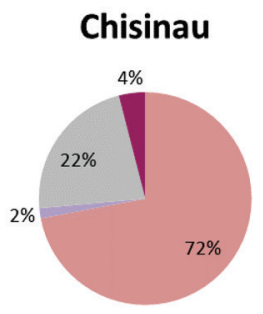

Bishkek

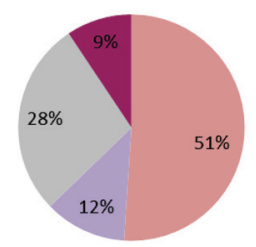

Wouldn't change anything

Would change the university, but not the faculty/specialty

Would change the faculty/specialty

- I find it difficult to answer.

Figure 3. Distribution of students' answers to the question of what they would change hypothetically. Source: The Survey data.

\section{Regression analysis of migration intentions of students: comparison of medical students with other respondents}

Within the framework of the Survey, various groups of factors that can influence the decision of the students not to return homeward were analyzed. As a result, we confirmed the first hypothesis that the perspective to return to hometown for the graduates are less when the wage expectations are low.

The second hypothesis, related to stronger effect of factors stimulating return after graduation among medical students compared to the totality of graduates, was also confirmed in the course of the analysis.

\section{Data description}

The questionnaire consisted of 14 sections, which covered the profile and characteristics of educational institutions, socio-economic situation of respondents and their prospects (including expectations from migration), socio-economic characteristics of the regions of origin and places of study.

The regression analysis took into account 1,907 observations on the total sample of students $(28.38 \%$ of the total number of respondents). This number of observations enabled analysis not only of basic variables, but also of respondents' responses to more complex questions. For the purpose of basic separation of students of medical and non-medical specialties, a binary variable was taken, which was 1 for medical students and 0 for students of other specialties.

\section{Building Variables}

The results of previous studies (Sage et al. 2013; Rérat 2014a) were taken into account when selecting variables that are important for the validation of significance. 
A binary variable was used as the dependent one, which is equal to:

- for non-resident students: 1 if the respondent is not going to return to his native settlement after graduation, and 0 if he is;

- for local students: 1 if the respondent is going to leave their native settlement after graduation, and 0 if not.

Thus, the value of 1 was assigned to students with migration intentions, the value 0 was assigned to those who did not. It is important to note that this did not take into account the direction of further migration of the respondent. On the one hand, in the framework of this research, the study of factors and measures of retention of graduates in the native region is put as the main issue. On the other hand, this is due to the relatively low percentage of those who plan to move abroad after graduation: $3.2 \%$ of all specialties and $4.7 \%$ of medical students. At the same time, it should be noted that in capital universities: in I.M. Sechenov First Moscow State Medical University and I.P. Pavlov First Saint-Petersburg Medical Academy the proportion of respondents who want to move abroad in the future is almost three times higher than in regional educational institutions, and is respectively 9 and $7 \%$.

A large number of indicators were analyzed as independent variables (in addition to the previously mentioned variable distinguishing students of medical and non-medical specialties). They can be classified into 5 groups:

1. The current welfare of the student

This group includes wages (for working students) and monthly income (regardless of source of income). The logarithm of monthly income was included in the final specification.

2. Social characteristics of the respondent

This group includes indicators of the age of the student, the presence of children, spouse (s) or partner, gender. All variables were included in the final specification, as well as the interaction variable between the presence of children and the spouse (s)/partner.

3. Education

In this group, the grades of the students were taken into account (the binary variable of good/bad grades equal to 1 if it is an A or B student or has a minimum percentage of $\mathrm{C}$ grades in the absence of $\mathrm{E}$ grades), whether he/she has plans to continue academic education, if he/she is an employer-backed enrolled student ( 1 if yes, 0 if no), and whether or not his/her father and mother have a university education. The final specification includes only the variables of availability of plans for continuing education and being an employer-backed enrolled student.

4. Financial situation of the family

This group includes the following variables: (1) presence / absence of job for the father and mother, (2) the level of family wellbeing (categorical variables of high, medium and low level of wellbeing), (3) financial assistance to parents by the respondent, (4) financing of the student by the parents, (5) availability of a job for the student (concurrently with studies). The second, third and fifth variables were taken into account in the specification.

5. Socio-economic characteristics of the native settlement

Variables of the following parameters have been built: (1) characteristics of the level of prosperity of the region (higher or lower than the average in Russia); (2) chances of employment for a person without work experience (high or low); (3) chances of employment for a person with work experience (high or low); (4) matching the expected level of wages with the income of a medium- or high- income family. These variables were built on the students' responses to relevant questions and reflect subjective assessments of respondents. None of the variables were included in the final specification because there were few answers to the 
questions. In the framework of further research it is important to work with this group of variables, as it enables determining the impact of socio-economic characteristics of the place from which the respondent came for training, on making the decision on return and directions of further migration.

\section{Results}

All constructed variables were analyzed in groups and jointly. The resulting specification is presented in Table 3.

Table 3. Analysis of factors influencing the decision of students not to return homeward with special focus on students of medical specialties.

\begin{tabular}{|c|c|}
\hline & Has no intention to return homeward \\
\hline \multirow[t]{2}{*}{ Medic } & $-0.446^{\star * *}$ \\
\hline & $(0.161)$ \\
\hline \multirow[t]{2}{*}{ Logarithm of monthly income } & $0.0182^{\star}$ \\
\hline & $(0.00934)$ \\
\hline \multirow[t]{2}{*}{ Logarithm of monthly income (medical specialties) } & $0.0374^{\star *}$ \\
\hline & $(0.0172)$ \\
\hline \multirow[t]{2}{*}{ Male } & -0.0212 \\
\hline & $(0.0164)$ \\
\hline \multirow[t]{2}{*}{ Male (medical specialties) } & 0.0186 \\
\hline & $(0.0324)$ \\
\hline \multirow[t]{2}{*}{ Married } & -0.0268 \\
\hline & $(0.0213)$ \\
\hline \multirow[t]{2}{*}{ Married (medical specialties) } & -0.0561 \\
\hline & $(0.0380)$ \\
\hline \multirow[t]{2}{*}{ Has children } & 0.0162 \\
\hline & $(0.0375)$ \\
\hline \multirow[t]{2}{*}{ Has children (medical specialties) } & $-0.362^{\star * *}$ \\
\hline & $(0.0897)$ \\
\hline \multirow[t]{2}{*}{ Has children and married } & $0.277^{* * *}$ \\
\hline & $(0.0946)$ \\
\hline \multirow[t]{2}{*}{ Provides financial assistance to parents } & 0.0200 \\
\hline & $(0.0175)$ \\
\hline
\end{tabular}

Provides financial assistance to parents (medical

specialties) $-0.0590^{*}$

$(0.0320)$

High level of family welfare $\quad 0.00529$

(0.0184) 


\begin{tabular}{|c|c|}
\hline & Has no intention to return homeward \\
\hline \multirow[t]{2}{*}{ High level of family welfare (medical specialties) } & -0.0453 \\
\hline & $(0.0380)$ \\
\hline \multirow[t]{2}{*}{ Low level of family welfare } & 0.0151 \\
\hline & $(0.0242)$ \\
\hline \multirow{2}{*}{ Low level of family welfare (medical specialties) } & 0.0613 \\
\hline & $(0.0403)$ \\
\hline \multirow[t]{2}{*}{ Has a job } & 0.0191 \\
\hline & $(0.0168)$ \\
\hline \multirow[t]{2}{*}{ Plans to continue studying at university } & 0.0119 \\
\hline & $(0.0156)$ \\
\hline \multicolumn{2}{|l|}{ Plans to continue studying at university } \\
\hline \multirow[t]{2}{*}{ (medical specialties) } & $0.0840^{* * *}$ \\
\hline & $(0.0285)$ \\
\hline \multirow[t]{2}{*}{ Employer-backed enrolled student } & -0.0112 \\
\hline & $(0.0422)$ \\
\hline \multirow[t]{2}{*}{$\begin{array}{l}\text { Employer-backed enrolled student (medical speci } \\
\text { ties) }\end{array}$} & $-0.188^{\star * *}$ \\
\hline & $(0.0506)$ \\
\hline \multirow[t]{2}{*}{ Constant } & $0.756^{\star * *}$ \\
\hline & $(0.0870)$ \\
\hline Number of observations & 1907 \\
\hline $\mathrm{R}^{2}$ & 0.117 \\
\hline
\end{tabular}

The ${ }^{*}$ symbol in the table indicates the level of importance of coefficients: ${ }^{* *} p<0.01,{ }^{* *} p<0.05,{ }^{*} p<0.1$.

The results of the analysis bring us to the following conclusions:

1. In general, medical students are more likely to return homeward after graduation than students of other specialties.

2. The current stable financial condition of the respondent increases the possibility of his/her non-return homeward, and for medical students the effect of this factor is stronger than for students of other specialties.

3. Virtually all variables are insignificant for students of non-medical specialties, but some factors can be controlled for individual specialties.

4. Presence of children has a stronger positive impact on medical students' decision to return homeward in comparison with students of other specialties; this is probably due to the need of support from the older generation when upbringing children and is to be combined with professional activities.

5. The fact that the respondent has his own family (the spouse and children) is significant in the decision not to return to the hometown; probably after a young family has already settled down at the current place of residence it is not convenient and not necessary for it to migrate. 
6. The family welfare factor is especially important for medical students: among students providing financial assistance to their families, medical students have a higher probability to return homeward than students of other specialties; this fact may be associated with a higher altruism of future doctors.

7. Quite expectably, for employer-backed enrolled students the probability to return homeward is increased and their intention to continue education is reduced; both trends are stronger for medical students and insignificant for students of non-medical specialties. The latter can be explained by the results of the previous statistical analysis: students of non-medical specialties show less satisfaction with their specialty and education profile than medical students, so it is not surprising that they are reluctant to continue their studies at their university or work in their specialty. It should be also mentioned that the percentage of non-medical employer-backed enrolled students was generally low.

8. At a $20 \%$ level, the following factors appeared significant:

- the factor of marriage: for students of all specialties this increases the probability of returning homeward, for medical students the effect is stronger. Clarification in connection with the conclusion in item 5: here we speak about respondents who are marries but do not have children, that is, the birth of a child is a significant turning point in this context;

- the factor of gender: men are more likely to return homeward than women.

Generally, there is an important difference between students of medical specialties and others: social factors are more important for the former (financial support to the family, the presence of children); while for the latter, at this stage of work it turned almost impossible to identify common patterns apart from the economic factor of income. Thus, medical students can be characterized as a more integrated group of respondents. Taking into account the importance of non-economic factors for medical students, we can conclude that migration strategy of this group of respondents can be significantly influenced by measures of social and economic policy aimed at attracting doctors to small towns and villages (the "Zemsky Doctor" program), and also by personal features of medical students (in particular, a higher level of altruism and a more conscious approach to the choice of specialty).

\section{Conclusion}

In the course of the analysis, the tasks set at the beginning of the work were solved with the following results:

1) the research on the causes and processes of internal and international migration (taken together) among university graduates shows the multifactor nature of this process, with economic factors having a major role;

2) in general, graduates of Russian universities are not eager to return homeward, and often such decisions are forced in nature (in the framework of employer-backed enrollment);

3) graduates of medical specialties are more conscious in choosing the direction of study and, therefore, demonstrate higher willingness to work in healthcare. When deciding to move, medical students are less susceptible to economic factors than students in other fields; social factors for them are more important. 
It should be noted that the key influence of the level of development of the native region of the student on the probability of his/her return argued by the global academic literature, is even more significant in Russia due to strong economic differentiation of regions, so more research is needed to analyze the impact of this factor. Medical students are also affected by this imbalance but are less sensitive to it, and it can be assumed that, in this context, improvements in working conditions in cities non-central for their regions, will have a significant effect and will result in an increase in the "settling" of young doctors in native settlements. The importance of social factors for this group of graduates potentially means that this channel (raising the prestige of the profession in the public mind, the growth of social benefits) is also capable of producing a positive impact not only on a more equitable distribution of medical workers across regions, but also on the growth of their numbers as a whole.

\section{Financial disclosure}

The study was carried out with the financial support of the Russian Foundation for Basic Research, project № 19-010-0067019

\section{Reference list}

Aronson JK (2011) How to attract, retain and nurture young academic clinicians. Journal of the Royal Society of Medicine 101(4): 6-14. doi: 10.1258/jrsm.2010.100248.

Boncea I (2015) Brain Drain or Circular Migration: The Case of Romanian Physicians. Procedia Economics and Finance 32: 649-653 doi: 10.1016/s2212-5671(15)01445-8.

Chem obernetsya Putinskaya initsiativa "Zemskii doktor": poedut starye vrachi [What will the Putin's initiative "Zemksii doctor" turn out: the elderly doctors will go] MK.RU, 20.02.2019. URL: https://www.mk.ru/politics/2019/02/20/chem-obernetsya-putinskaya-iniciativa-zemskiy-doktor-poedut-starye-vrachi.html [Access on 20.11.19]

Chislennost' vrachei v Rossii uvelichilas' do 549 tysyach [Number of doctors in Russia increased up to 549 thousand] Medvestnik, 25.04.2019. URL: https://medvestnik.ru/content/news/Chislennostvrachei-v-Rossii-uvelichilas-do-549-tysyach.html [Access on 20.11.19]

Chudinovskikh OS, Denisenko MB, Donets EV (2003) Migratsionnye namereniya vypusknikov rossiiskikh vysshikh uchebnykh zavedenii (Metodika provedeniya i osnovnye rezul'taty vyborochnogo obsledovaniya) [Migration intentions of graduates of Russian higher educational institutions (Methods of conducting and main results of the sample survey)] MAKS-Press, Moscow. (in Russian)

Denisenko MB, Chudinovskikh OS (2015) K voprosu ob organizatsii migratsii meditsinskikh rabotnikov [On the issue of management of migration of medical workers] In: Donets EV, Chudinovskikh OS (Eds) Sovremennye issledovaniya migratsii naseleniya [Contemporary studies in migration of population]. Demographic Studies Series, vol. 26, pp. 31-49. (in Russian)

Dustmann C, Glitz A (2011) Migration and Education. In: Hanushek EA, Machin S, Woessmann L (Eds.) Handbook of the Economics of Education. Elsevier, Amsterdam. Vol. 4, pp. 327-439.

Faggian A, McCann P (2009) Human capital, graduate migration and innovation in British regions. Cambridge Journal of Economics 33(2): 317-333.

Fargues P (2019) International Migration and Education - A Web of Mutual Causation. URL: https:// es.unesco.org/gem-report/sites/gem-report/files/Fargues_International\%20Migration\%20and\%20 Education.pdf 
Federal Law of 01.05.2016 N 124-FL On Amendments to Articles 14 and 30 of the Federal Law 'On Citizenship of the Russian Federation'. Digital resource: http://base.garant.ru/71388660/ (access mode: 16.11.2019). (in Russian)

Federal Law of 03.07.2019 N 165-FL On Amendments to Article 14 of the Federal Law 'On Citizenship of the Russian Federation' Consultant-Plus. Digital resource: http://www.consultant.ru/document/ cons_doc_LAW_328147/ (access mode: 16.11.2019). (in Russian)

Fielding AJ (1992) Migration and Social Mobility: South East England as an Escalator Region. Regional Studies 26(1): 1-15.

Gorbacheva EA (2007) Osobennosti migratsionnogo povedeniya studencheskoi molodezhi [Features of migration behaviour of students of Omsk oblast] PhD thesis, Institute of Socio-Political Studies of the Russian Academy of Sciences, Moscow. (in Russian)

Haartsen T, Thissen F (2014) The success-failure dichotomy revisited: Young adults' motives to return to their rural home region. Children's Geographies 12(1): 87-101.

Halfacree K (2004) A Utopian imagination in migration's Terra Incognita? Acknowledging the non-economic worlds of migration decision-making. Population, Space and Place 10(3): 239-253.

Heckert J (2015) New perspective on youth migration: Motives and family investment patterns. Demographic Research 33(1): 765-800.

Jenny M (2013) International Student Migration: Outcomes and Implications. Journal of International Students 3(2): 167-181.

Kak $\mathrm{v}$ regionakh boryutsya s nekhvatkoi vrachei [How regions combat shortages of medical workers] Rossiiskaya Gazeta N 165(7923), 29.07.2019. URL: https://rg.ru/2019/07/29/reg-sibfo/kak-v-regionah-boriutsia-s-nehvatkoj-vrachej.html [Accessed on 20.11.19]

Kak v regionakh sochinyayut meditsinskie programmy [How they make up medical programmes in the regions] Medvestnik, 28.03.2018. URL: https://medvestnik.ru/content/articles/Kak-v-regionah-sochinyaut-medicinskie-programmy.html [Accessed on 20.11.19]

Kalashnikov KN, Likhacheva TN (2017) Sotsial'nye problemy razvitiya territorii [Social problems of territorial development]. Voprosy territorial'nogo razvitiya 2(37): 1-18. (in Russian)

Kashnitsky IS (2015) Migratsiya molodezhi v Rossii: vliyanie na vozrastnye struktury [Youth migration in Russia: influence on age structures] In: In: Donets EV, Chudinovskikh OS (Eds.) Sovremennye issledovaniya migratsii naseleniya [Contemporary studies in migration of population]. Demographic Studies Series, vol. 26, pp. 79-93. (in Russian)

Kerr SP, Kerr W, Ozden C, Parsons C (2016) Global Talent Flows. The Journal of Economic Perspectives 30(4): 83-106.

Ledenyova LI (1995) Ehmigratsionnye namereniya studentov krupnykh gorodov Evropeiskoi chasti byvshego SSSR [Emigration intentions of students of major cities of the European part of the former USSR] PhD thesis, Institute of Economic Forecasting of the Russian Academy of Sciences, Moscow. (in Russian)

Minzdrav nadeetsya reshit' problemu nekhvatki meditsinskikh kadrov navsegda [Ministry of health hopes to solve the problem of medical staff shortage forever] Medvestnik, 01.08.2017. URL: $\quad$ https://medvestnik.ru/content/news/Minzdrav-nadeetsya-reshit-problemu-nehvatki-medicinskih-kadrov-navsegda.html [Accessed on 20.11.19] (in Russian)

Order of the Ministry of Labour and Social Protection of the Russian Federation of 13.07.2015 № 446n On approval of the list of professions (specialties, positions) of foreign citizens and stateless persons - qualified specialists who have the right to obtain citizenship of the Russian Federation in a simplified procedure. Digital resource: https://www.garant.ru/products/ipo/prime/doc/71046102/ [Accessed on 16.11.2019] (in Russian) 
Perry JJ, Clark C (2012) Medical Malpractice Liability and Physician Migration. Business Economics. Palgrave Macmillan Journal 47(3): 202-213.

Ramos P, Alves H (2017) Migration intentions among Portuguese junior doctors: results from a survey. Health Policy 121(12): 1208-1214.

Rérat P (2014a) Highly qualified rural youth: Why do young graduates return to their home region? Children's Geographies 12(1): 70-86.

Rérat, P (2014b) The selective migration of young graduates: which of them return to their rural home region and which do not? Journal of Rural Studies 35: 123-132.

Rose A, Janse van Rensburg-Bonthuyzen E (2015) South African family practice: the factors that attract healthcare professionals to and retain them in rural areas in South Africa, South Africa. South African Family Practice 57(1): 44-49.

Roshal L (2019) Raspredelyat' vypusknikov nuzhno ne na katorgu, a v normal'nye usloviya [High school graduates are to be assigned not to drudgery but to normal conditions] Medvestnik, 02.09.2019. URL: https://medvestnik.ru/content/news/Leonid-Roshal-raspredelyat-vypusknikov-nujno-ne-na-katorgu-a-v-normalnye-usloviya.html [Accessed on 20.11.19] (in Russian)

Sage J, Evandrou M, Falkingham J (2013) Onwards or homewards? Complex graduate migration pathways, well-being, and the 'parental safety net'. Population, Space and Place 19(6): 738-755.

Statistical Digest (2017) Digital resource: https://www.rosminzdrav.ru/ministry/61/22/stranitsa-979/ statisticheskie-i-informatsionnye-materialy/statisticheskiy-sbornik-2017-god [Accessed on 5.11.2019] (in Russian)

Tarasenko EA, Khoreva OB (2016) Ehkonomicheskoe stimulirovanie dlya ustraneniya defitsita meditsinskikh kadrov v sel'skikh territoriyakh [Economic stimulation to eliminate the shortage of medical personnel in rural areas] Voprosy gosudarstvennogo i munitsipal'nogo upravleniya 4: 117-142. (in Russian)

Varshavskaya EY, Chudinovskikh OS (2014) Migratsionnye plany vypusknikov regional'nykh vuzov Rossii [Migration plans of graduates of regional universities of Russia] Vestnik Moskovskogo universiteta. Series 6: Economics (3): 36-58. (in Russian)

Verma $P$ et al. (2016) A systematic review of strategies to recruit and retain primary care doctors. BMC Health Services Research. BioMed Central Ltd. 16(1).

Wu C, Wilkes R (2017) 'International students' post-graduation migration plans and the search for home. Geoforum 80: 123-132.

\section{Information about the author:}

- Valeriia Gennadievna Oksinenko, Laboratory of Population Economics and Demography, Faculty of Economics of the Lomonosov Moscow State University. E-mail: leraoksinenko@gmail.com 
Annex 1. Acronyms and full names of higher education institutions covered by the Survey.

\begin{tabular}{|c|c|}
\hline Acronym & Full name \\
\hline Baikal State University & Baikal State University \\
\hline Bashkir State University & Bashkir State University \\
\hline Immanuel Kant BFU & Immanuel Kant Baltic Federal University BFU \\
\hline ISMU MH of Russia & $\begin{array}{l}\text { Irkutsk State Medical University of the Ministry of } \\
\text { Health Care of Russia }\end{array}$ \\
\hline Kemerovo State University & Kemerovo State University \\
\hline Lomonosov Moscow State University & Lomonosov Moscow State University \\
\hline Naberezhnye Chelny Institute of KFU & $\begin{array}{l}\text { Naberezhnye Chelny Institute of Kazan (Volga) Federal } \\
\text { University }\end{array}$ \\
\hline NRU HSE & $\begin{array}{l}\text { National Research University Higher School of Eco- } \\
\text { nomics }\end{array}$ \\
\hline Nizhny Novgorod Branch of NRU HSE & $\begin{array}{l}\text { Nizhny Novgorod Branch of the National Research } \\
\text { University Higher School of Economics }\end{array}$ \\
\hline Dostoevsky OmSU & Dostoevsky Omsk State University \\
\hline Vagner PSMA University & Vagner Perm State Medical University \\
\hline PSRU & Perm State Research University \\
\hline Perm Branch of NRU HSE & $\begin{array}{l}\text { Perm Branch of the National Research University High- } \\
\text { er School of Economics }\end{array}$ \\
\hline $\begin{array}{l}\text { Sechenov First Moscow State Medical } \\
\text { University }\end{array}$ & Sechenov First Moscow State Medical University \\
\hline Pavlov FSPbMU & Pavlov First Saint-Petersburg Medical University \\
\hline RSUH & Russian State University for the Humanities \\
\hline RSMU & Rostov State Medical University \\
\hline Mendeleev UCTR & $\begin{array}{l}\text { D.Mendeleev University of Chemical Technology of } \\
\text { Russia }\end{array}$ \\
\hline SamSMU MH of Russia & $\begin{array}{l}\text { Samara State Medical University of the Ministry of } \\
\text { Health Care of Russia }\end{array}$ \\
\hline St.Petersburg branch of the NRU HSE & $\begin{array}{l}\text { St. Petersburg Branch of the National Research Univer- } \\
\text { sity Higher School of Economics }\end{array}$ \\
\hline SPbSU & Saint Petersburg State University \\
\hline USATU & Ufa State Aviation Technical University \\
\hline USMU MH of Russia & $\begin{array}{l}\text { Ural State Medical University of the Ministry of Health } \\
\text { Care of Russia }\end{array}$ \\
\hline USPTU & Ufa State Petroleum Technological University \\
\hline USUE & Ural State University of Economics \\
\hline USUES & Ufa State University of Economics and Service \\
\hline Southern Federal University & Southern Federal University \\
\hline
\end{tabular}


Annex 2. Distribution of respondents by higher education institutions and financial forms of education (medical universities are presented in boxes)

Financial form of education

\begin{tabular}{|c|c|c|c|}
\hline Name of the university & Commercial & Budget & Total \\
\hline Bashkir State University & 37 & 69 & 106 \\
\hline Vagner PSMA University & 18 & 184 & 202 \\
\hline SamSMU MH of Russia & 53 & 297 & 350 \\
\hline USMU MH of Russia & 67 & 188 & 255 \\
\hline ISMU MH of Russia & 78 & 205 & 283 \\
\hline USATU & 8 & 31 & 39 \\
\hline USPTU & 42 & 129 & 171 \\
\hline Kemerovo State University & 33 & 256 & 289 \\
\hline Lomonosov Moscow State University & 104 & 749 & 853 \\
\hline NRU HSE & 101 & 264 & 365 \\
\hline Naberezhnye Chelny Institute of KFU & 157 & 99 & 256 \\
\hline Nizhny Novgorod Branch of NRU HSE & 21 & 86 & 107 \\
\hline Dostoevsky Omsk State University & 73 & 216 & 289 \\
\hline Pavlov FSPbMU & 46 & 189 & 235 \\
\hline Sechenov First Moscow State Medical University & 60 & 225 & 285 \\
\hline PSRU & 79 & 221 & 300 \\
\hline Perm Branch of NRU HSE & 19 & 113 & 132 \\
\hline RSUH & 55 & 124 & 179 \\
\hline Mendeleev UCTR & 5 & 139 & 144 \\
\hline Rostov State Medical University & 50 & 215 & 265 \\
\hline $\mathrm{SPbSU}$ & 21 & 233 & 254 \\
\hline Saint-Petersburg Branch of the NRU HSE & 6 & 58 & 64 \\
\hline USUE & 79 & 125 & 204 \\
\hline USUES & 16 & 65 & 81 \\
\hline Immanuel Kant BFU & 53 & 249 & 302 \\
\hline Baikal State University & 173 & 124 & 297 \\
\hline Southern Federal University & 44 & 288 & 332 \\
\hline Total & 1498 & 5141 & 6639 \\
\hline Per cent & $22,56 \%$ & $77,44 \%$ & $100 \%$ \\
\hline
\end{tabular}

Source: The Survey data 


\section{Annex 3}

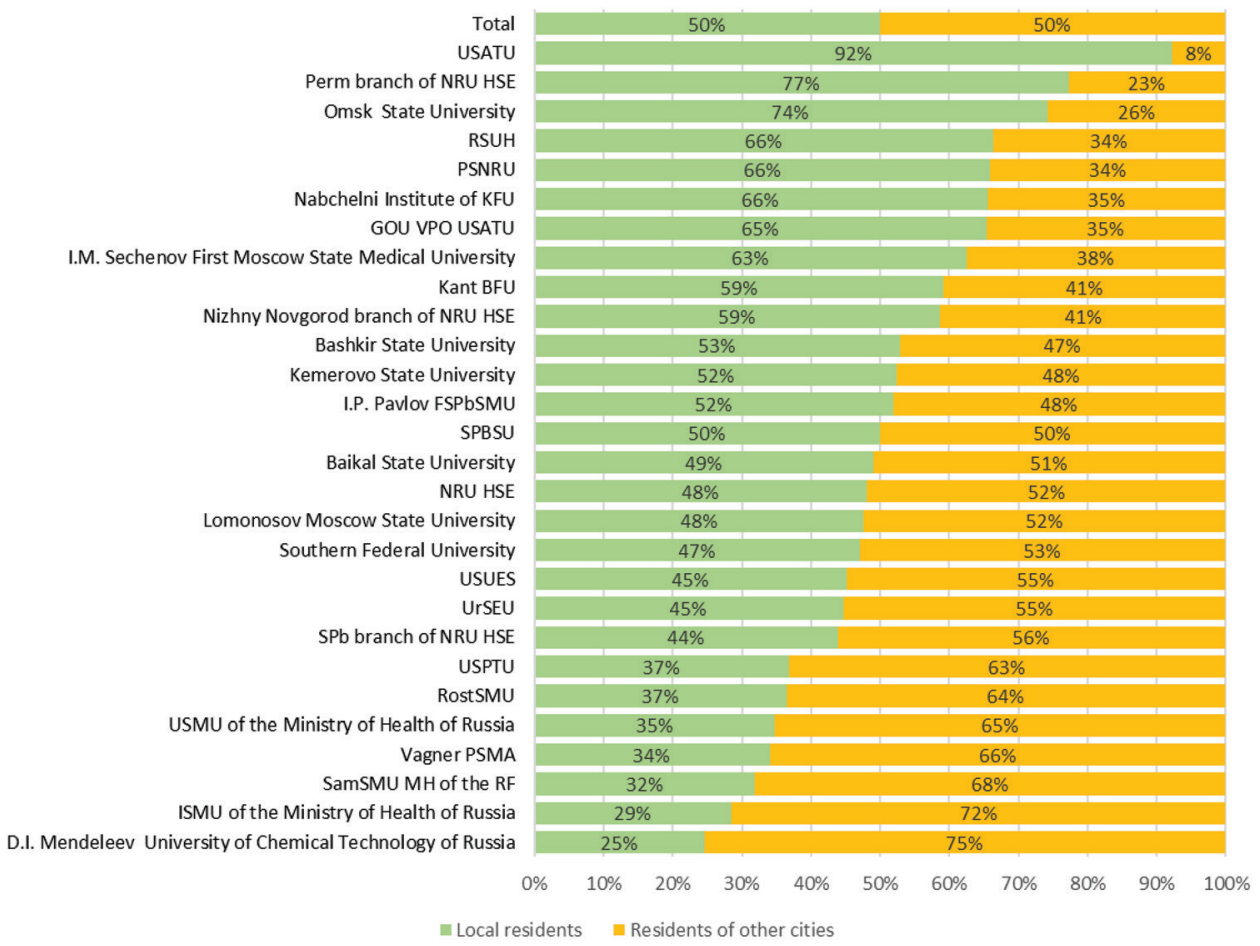

Figure A3.1 Distribution of respondents by place of residence before admission to higher education institution (percentage). Source: The Survey data

Total

\begin{tabular}{|c|c|}
\hline $40 \%$ & $60 \%$ \\
\hline $63 \%$ & $38 \%$ \\
\hline $52 \%$ & $48 \%$ \\
\hline $32 \%$ & $68 \%$ \\
\hline $37 \%$ & $64 \%$ \\
\hline $35 \%$ & $65 \%$ \\
\hline $29 \%$ & $72 \%$ \\
\hline $34 \%$ & $66 \%$ \\
\hline $60 \%$ & $40 \%$ \\
\hline
\end{tabular}

ISMU of the Ministry of Health of Russia

USMU of the Ministry of Health of Russia

Vagner PSMA

Kant BFU

$\begin{array}{llllllllllll}0 \% & 10 \% & 20 \% & 30 \% & 40 \% & 50 \% & 60 \% & 70 \% & 80 \% & 90 \% & 100 \%\end{array}$

- Local residents

Residents of other cities

Figure A3.2 Distribution of respondents from medical universities by place of residence before admission to higher education institution (percentage). Source: The Survey data 
Annex 4. Distribution of employer-back enrolled respondents, by higher education institutions (medical universities are presented in boxes)

\begin{tabular}{|c|c|c|c|c|c|}
\hline \multirow[b]{3}{*}{ Bashkir State University } & \multicolumn{2}{|l|}{ Local } & \multicolumn{2}{|c|}{$\begin{array}{l}\text { Residents of other } \\
\text { cities }\end{array}$} & \multirow[b]{2}{*}{ Total } \\
\hline & pers. & share, in \% & pers. & share, in \% & \\
\hline & 3 & $27,3 \%$ & 8 & $72,7 \%$ & 11 \\
\hline Vagner PSMA University & 2 & $5,4 \%$ & 35 & $94,6 \%$ & 37 \\
\hline SamSMU MH of Russia & 4 & $3,4 \%$ & 114 & $96,6 \%$ & 118 \\
\hline USMU MH of Russia & 14 & $17,9 \%$ & 64 & $82,1 \%$ & 78 \\
\hline ISMU MH of Russia & 1 & $2,0 \%$ & 48 & $98,0 \%$ & 49 \\
\hline Kemerovo State University & 1 & $20,0 \%$ & 4 & $80,0 \%$ & 5 \\
\hline Lomonosov Moscow State University & 5 & $71,4 \%$ & 2 & $28,6 \%$ & 7 \\
\hline NRU HSE & 5 & $83,3 \%$ & 1 & $16,7 \%$ & 6 \\
\hline Naberezhnye Chelny Institute of KFU & 2 & $100,0 \%$ & & $0,0 \%$ & 2 \\
\hline Dostoevsky Omsk State University & 19 & $79,2 \%$ & 5 & $20,8 \%$ & 24 \\
\hline Pavlov FSPbMU & 6 & $46,2 \%$ & 7 & $53,8 \%$ & 13 \\
\hline Sechenov First Moscow State Medical University & 11 & $57,9 \%$ & 8 & $42,1 \%$ & 19 \\
\hline PSRU & 8 & $61,5 \%$ & 5 & $38,5 \%$ & 13 \\
\hline RSUH & 3 & $30,0 \%$ & 7 & $70,0 \%$ & 10 \\
\hline Mendeleev UCTR & 2 & $13,3 \%$ & 13 & $86,7 \%$ & 15 \\
\hline Rostov State Medical University & 12 & $12,6 \%$ & 83 & $87,4 \%$ & 95 \\
\hline SPbSU & 3 & $50,0 \%$ & 3 & $50,0 \%$ & 6 \\
\hline USUE & 5 & $41,7 \%$ & 7 & $58,3 \%$ & 12 \\
\hline USPTU & 3 & $37,5 \%$ & 5 & $62,5 \%$ & 8 \\
\hline USUES & 6 & $100,0 \%$ & & $0,0 \%$ & 6 \\
\hline Immanuel Kant BFU & 13 & $72,2 \%$ & 5 & $27,8 \%$ & 18 \\
\hline Baikal State University & 3 & $100,0 \%$ & & $0,0 \%$ & 3 \\
\hline Southern Federal University & 4 & $33,3 \%$ & 8 & $66,7 \%$ & 12 \\
\hline Total & 129 & $22,8 \%$ & 438 & $77,2 \%$ & 567 \\
\hline
\end{tabular}

Source: The Survey data 